\title{
Manevi Zekanın İç Yönelimli Dindarlık, Affetme Esnekliği ve Öznel İyi Oluşla İlişkisi
}

\author{
Ahmet Canan KARAKAŞ \\ Yrd. Doç. Dr., Karabük Üniversitesi İlahiyat Fakülteesi \\ Asst Prof. Dr., Karabuk University, Theology Faculty \\ Orcid ID: 0000-0002-7478-8123 \\ ackarakas@yahoo.com
}

Öz

Manevi zekâ bireyin hayatın sıkıntıları ile baş etme sürecinde etkisi olan geliştirilebilir bir yetenektir. İç yönelimli dindarlık ve affetme ise manevi zekâ ile ilintilidir. Bu beceriler geliştirildiğinde öznel iyi oluş psikolojik iyi olma hali artabilir. Bu çalışmada manevi zekanın iç yönelimli dindarlık, affetme esnekliği ve öznel iyi oluşa etkisi ve aralarındaki ilişki araştırılmıştır. Değişkenler arasında anlamlı düzeyde pozitif ilişki gözlenmiştir. Ancak değişkenlerde cinsiyet ve fakülte açısından aralarında anlamlı bir fark bulunmamıştır. Çoklu regresyon analizi sonuçlarına göre affetme esnekliği, iç yönelimli dindarlık ve öznel iyi oluş manevi zekanın \%12,9'nu açıladığı görülmüştür. Bireyin manevi zekâsı geliştiğinde affetme esnekliği ve iç güdümlü dindarlığı da gelişebileceği gözlenmiştir.

Anahtar Kelimeler: Manevi Zekâ, Öznel İyi Oluş, Affetme Esnekliği, İç Yönelimli Dindarlık, Afv.

\section{Relation of Spiritual Intelligence to Intrinsic Religiosity, Forgiveness Flexibility and Subjective Well-Being}

\begin{abstract}
Spiritual intelligence is an improvable skill that is influential in the process of coping with the difficulties of the individual. Intrinsic religiosity and forgiveness relate to spiritual intelligence. When these skills are developed, subjective well-being and psychological well-being may increase. In this study, the relationship between spiritual intelligence, intrinsic religiosity, forgiveness, and subjective well-being influence have been investigated. There was a significant positive correlation between the variables. There was a significant positive correlation between the variables. However, there was no significant difference between the variables in terms of gender and faculty. According to the results of multiple regression analysis, forgiveness flexibility, intrinsic religiosity, and subjective well-being were found to account for $12.9 \%$ of spiritual intelligence. When the individual's spiritual intelligence evolved, it was observed that forgiveness flexibility and intrinsic religiosity could also develop.
\end{abstract}

Keywords: Spiritual Intelligence, Subjective Well-Being, Forgiveness Flexibility, Intrinsic Religiosity, Forgiveness. 
Manevi Zekanın İç Yönelimli Dindarlık, Affetme Esnekliği ve Öznel İyi Oluşla İlişkisi/ Relation of Spiritual Intelligence to Intrinsic Religiosity, Forgiveness Flexibility and Subjective Well-Being

\section{Giriș:}

İnsanın analitik ve matematiksel becerisini konu alan zekâ türü IQ keşfinden sonra zekâ araştırmaları devam etmiş olup başka zekâ türleri de olabileceği düşünülmüştür.

Howard Gardner, 'Frame of Mind (Zihin Çerçeveleri)' isimli kitabıyla 'çoklu zekâ' kavramından yola çıkarak farklı tartışma ve araştırma alanları açtı. Kitapta yedi farklı zekâ türünden bahsetmektedir. Bunlar; dilsel, analitik ve matematiksel, müziksel, bedensel, uzaysal/uzamsal, kişisel ve içsel zekâdır. Yine dört zekâ modelinden bahsederek bunları tabandan tavana fiziksel zekâ, dilsel ve matematiksel beceri zekâsı olan IQ, duygusal zekâ (EQ) ve spritüal zekâ (SQ) diye sıralamaktadır. EQ ve SQ birbiriyle yakından ilişkisi olan zekâ türleridir. Bu iki zekâ türü düşünceden, fiziksel ve analitik düşünceden ziyade duygulara hitap eden zekâ türleridir (Zohar \& Marshall, 2014, s:16). Özellikle SQ doğrudan kalbi muhatap alan ve akleden kalp denebilecek zekâ türünü açılamak için araştırılmaya değer bir alan teşkil etmektedir.

Manevi zekâ insan beyninin ve psişesinin içsel, fitrî bir yeteneğidir ve en derin kaynaklarını evrenin kalbinden çekip çıkarmaktadır. Bu milyonlarca yıl içinde gelişen ve beynin problemlerin çc̈zümünde anlam bulmasını ve anlamı kullanmasını sağlayan bir yetenektir (Zohar ve Marshall, 2014).

Öznel iyi oluş kavramı ilk olarak Bradburn (1969) tarafından ortaya atılmıştır (Kuyumcu, 2011). Bradburn, öznel iyi oluşu olumlu duygu (isteklilik, enerjik olma, kararlılık, ruhsal uyarılmışlık) ile olumsuz duygu (üzüntü, kaygı, korku, öfke, suçluluk, küçümseme) arasındaki denge olarak tanımlamıştır (Diener, Suh, \& Oishi, 1997).

Öznel iyi oluş kavramı, bireyin bilişsel bir değerlendirmeyle yaşamdan doyum aldığ yargısına varmasını ve yaşamda kendisine hoşnutluk veren olumlu duyguları, olumsuz duygulardan daha fazla hissedebilmesini tanımlamaktadır (Diener \& Diener, Most People are Happy, 1996). Öznel iyi oluş kavramının (a) olumlu duygulanım, (b) olumsuz duygulanım ve de (c) yaşam doyumu olmak üzere birbiriyle ilişkili, ancak birbirinden farklı üç öğenin bileşiminden oluştuğu söylenebilir. Bu tanıma göre, öznel iyi oluş kavramının en genel haliyle bireyin yaşamına ilişkin sahip olduğu duygu ve düşüncelerinin genel bir değerlendirmesini içerdiği görülmektedir (Türkdoğan \& Duru, 2012).

Affetme hem ahlaki açıdan bir erdem hem de bireyin ruh sağlığını iyileştirmeye pozitif etkisi olan manevi bir yetenektir. Affetme farklı şekillerde ele alınmaktadır. Birincisi, bireyin, Tanrı'nın kendisini affetmesiyle ilgili düşüncelerinin incelenmesidir. İkincisi ise bireyin kendisini, başkasını/başkalarını veya olumsuz hayat koşullarını affetmesidir. Bir başka ifadeyle kişi, kendisine suç işleyen birini ve kendisini affettiği/affetmediği gibi olumsuz hayat koşullarını da tolere ede(meye)bilir (Ayten, 2009).

Bireyin, önemli derecede haksızlığa uğramış olmasına rağmen dargınlık, olumsuz yargılama, ilgisiz davranma, kin duyma, öç alma, ödeşme hakkından vazgeçme ve hak

Türkiye İlahiyat Araştırmaları Dergisi 
etmediği halde suç işleyen kişiye karşı merhamet, sevgi, şefkat gibi olumlu duyguları teşvik ederek kişiye bir hediye sunması olarak tanımlanır (Enright, Gassin, \& Wu, 1992).

İçsel (iç güdümlü) din teslimiyet kavramı, bir kimsenin dini inancı uğruna yaşaması için bir motivasyon olarak tanımlanmaktadır. Bu durumda bireyin dini, bizzat bir amaç olarak değerlendirilmekte ve dışsal zorlama olmaksızın güdülen bir amaç olarak anlaşılmaktadır (Karaca, 2001).

Bu çalışmada manevi zeka ile affetme esnekliği, iç yönelimli dindarlık ve öznel iyi oluş arasında bir ilişki ve etkileşim olup olmadığı araştırılmıştır.

\section{Manevi Zekâ}

Manevî zekâ, kişinin uzman bilgisinin bir parçası olabilen birtakım yetenek ve yeterliliklerden oluşur. Manevî bilgi, kişinin uyum sağlayıcı problem-çözme davranışına yol gösterebilen bilgi tabanının bir parçasıdır. Meselâ, manevî oluşum tamamen kutsala ilişkin bir uzman bilgi tabanı bilgisi inşa etme ile ilgilidir. Maneviyat, bireylere bir bilgi kaynağı ve ilgi ve alakaların bir işlevi olarak hizmet edebilir, bireyler bu bilgi sürecinde az ya da çok maharetli hale gelir. Meselâ, kutsal metin incelemeleri ve manevî eğitim uygulamaları sayesinde manevî bilgi tabanının derinlik ve genişliği gelişip saflaşır (Emmons, 2008; Çev: Ali Ulvi Mehmedoğlu, Fatma Şengül).

Emmons 2008 Manevi zekanın ana unsurlarını aşağıdaki gibi sıralar:

1-Aşkın/müteal için fizikî ve maddî kapasite,

2-Yüksek bilinç durumlarını deneyimleme yeteneği,

3-Günlük yaşantıyı kutsal hale getirme yeteneği,

4-Sorunları çözmek için manevî kaynakları kullanma yeteneği,

5-Erdemli olma kapasitesi.

Unsurlar incelendiğinde maneviyat sadece dindarlıkla ilgili değildir. Çünkü ruhsal zekâ ruhun zekasıdır. Bu zekâ kendimize şifa vermek, kendimizi bütün haline getirmek için kullandığımız zekadır. Ruhsal zekâ egonun veya şuurlu zihnin ötesindeki bilgeliğe bağlı olan benliğin en derindeki parçasında yatan zekadır (Zohar \& Marshall, 2014, s:23).

Howard ve arkadaşları (2009) manevi zekâsı yüksek olan bireylerin birtakım özelliklerini şöyle sıralar:

- Açık ve esnek bir kalp

- Coşkulu

- Kişinin varlık deneyimi ve kutsal varlık farkındalığı

- Bireyin dünyaya ve diğerlerin saygılı olması ve hizmet etmesi

- Bireyin en yüksek değer etiği tarafından yönlendirilmesi.

Manevi Zekâ maneviyat ve değerlerle yakından bağlantılıdır, bu nedenle bir bireyi değişim ve dönüşüm hissi ile güçlendirebilir ve kendisine kültürel ve ruhsal sorunların çözülmesinde yardımcı olabilir. Bu nedenle, onu dönüştürüp bireylere tanrıyla ilgili sorunlarını çözmelerinde yardımcı olur ve onları kültürel ve sosyal sorunlarını daha iyi ve daha etkili bir şekilde çözmeye hazırlar (Khoshtinat, 2012). Manevi zekâyı

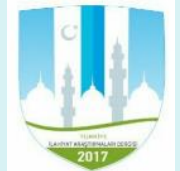


Manevi Zekanın İç Yönelimli Dindarlık, Affetme Esnekliği ve Öznel İyi Oluşla İlişkisi/ Relation of Spiritual Intelligence to Intrinsic Religiosity, Forgiveness Flexibility and Subjective Well-Being

geliştirmek teorikten ziyade yaşantısal bir süreçtir. Bu yüzden manevi zekâyı semboller ve metaforlar kullanmadan edebi terimlerle ifade etmek gerçek anlamda çok zordur. Manevi zekânın dili kalbin dilidir. Herkes onu anlar fakat sözlü olarak konuşmak için sezgi, hayal ve yaratıcılığın dilinden anlamak gerekir. Bu durum özellikle dini ve kültürel bir arka plana sahip çok kültürlü insanlar için geçerlidir (Söylemez, 2016). Manevi zekâ kalbi açar, zihni aydınlatır, ruha ilham kazandırır, bireyi ruhuyla iletişime geçirir. Kişi manevi zekâsını uygulamalarla geliştirebilir ve bunun sayesinde hakikati batıldan ayırt edebilir. Manevi zekâ bireyin tanrı merkezli bir şekilde hayatını anlamlandırma ve dünyayı yorumlama becerisi olabilir.

\section{Affetme:}

Affetme bireyin, önemli derecede haksızlığa uğramış olmasına rağmen dargınlık, olumsuz yargılama, ilgisiz davranma, kin duyma, öç alma, ödeşme hakkından vazgeçme ve hak etmediği halde suç işleyen kişiye karşı merhamet, sevgi, şefkat gibi olumlu duyguları teşvik ederek kişiye bir hediye sunması olarak tanımlanır.

Affetme, bireyin olumsuz duyguları hayatlarından uzaklaştırmasına ve tarafsız ya da olumlu bir duyguya dönüştürmesine yardımcı olan bir kavramdır (Çolak \& Koç, 2016).

Affetme eğilimi ile psikolojik refah arasındaki pozitif yüksek bir ilişki vardır. Bağışlama, deneyimli durumları kabul etmeye, kendisiyle ilişkileri objektif bir şekilde yapmaya, benliği olduğu gibi kabul etmeye ve tamamlanmamış işi tamamlamaya katkıda bulunan önemli bir faktördür (Koç, İskender, Çolak, \& Düşünceli, 2016).

\section{Öznel İyi Oluș:}

Bireylerin sahip oldukları olumlu ve olumsuz duygulara ve yaşamdan aldıkları doyuma ilişkin olarak yapmış oldukları öznel bir değerlendirmedir. Buna göre öznel iyi oluş, olumlu duyguların sık, olumsuz duyguların az yaşanması ve yüksek yaşam doyumu alma şeklinde tanımlanmaktadır (Diener, 1984).

Öznel iyi oluşun üç bileşeni olduğu kabul edilmiştir. Birincisi, yaşam doyumu; öznel iyi oluşun bilişsel bileşenidir. Bireyin çeşitli yaşam alanlarındaki doyumuna ilişkin değerlendirmelerini yansıtır (Myers \& Diener, 1995). İkincisi, olumlu duygulanım; neşe, ilgi, heyecan, güven, uyanıklık gibi duyguları yansıtmaktadır. Üçüncüsü olumsuz duygulanım; korku, öfke, nefret, suçluluk, üzüntü gibi olumsuz duyguları içeren doyumsuzluk ve öznel stresi tanımlamaktadır (Ben-Zur, 2003).

Öznel iyi oluşun yüksek olması için hoş olan duygulanımın hoş olmayan duygulanımdan daha çok yaşanması ve kişinin yaşamının niteliğine ilişkin bilişsel yargısının olumlu olması gerekmektedir (Aydınay Satan, 2014). Dindarlıkla öznel iyi oluş arasında pozitif anlamda bir ilişkiden bahsedilebilir. Yapılan araştırmaya göre Üniversite öğrencilerinin dini inançları güçlü olanların olmayanlara göre yaşam doyumlarının daha yüksek olduğu bulunmuştur (Aydınay Satan, 2014).

\section{Yöntem:}

Bu çalışma KBÜ İlahiyat Fakültesi, Fen Edebiyat Fakültesi ve Mühendislik Fakültesi öğrencileri ile yapılmış nicel bir araştırmadır. Araştırmada manevi zekâ, iç yönelimli

Türkiye İlahiyat Araştırmaları Dergisi 
dindarlık, affetme esnekliği ve öznel iyi oluş ölçekleri uygulanmıştır. Alınan sonuçlar SPSS 24. analiz programı ile değerlendirilirmiştir. Sonuçlarda aralarındaki korelasyon, farklılıklar ve regresyon analizleri çalışılmıştır.

\section{Veri Toplama:}

Manevi Zekâ Ölçeği (KF); çalışmamızda (Söylemez, Koç, \& Söylemez, 2016)' geçerlilik ve güvenilirliğini çalıştığı, 45 maddelik manevi zekâ ölçeği kısa formu uygulanmıştır. Ölçek likert olup "1. Asla veya hemen hemen hiç", "2. Çok nadir", "3. Nadir", "4. Sık”, "5.Çok sık”, "6. Her zaman veya hemen hemen her zaman” şeklinde ifadelendirilmiştir.

Affetme Esnekliği Ölçeği (AEÖ), bireyin affetme esnekliği olup olmadığını ölçmek için geliştirilen Likert tipi ölçektir. Ölçek 15 maddeden oluşmakta olup üç alt ölçeğe sahiptir. "Tanıma" alt ölçeği, "İçselleştirme" alt ölçeği "Uygulama" Katılımcılardan, her alt ölçeğin öğeleriyle birlikte açıklanan durumun ne kadarına uyduğuna dair derecelendirmeleri istenir 1 = "Kesinlikle Katılmıyorum", 2 = "Katılmıyorum", 3 = "Katılmıyorum", 4 = "Kabul ediyorum" ve 5 = "Kesinlikle katılıyorum". KMO değeri .85, Bartlett Sphericity Test $=1525.54$, p.=.000)dir (Çolak T. , 2013).

Öznel İyi Oluş Ölçeği, yasam alanlarına ilişkin kişisel yargılar ile olumlu ve olumsuz duygu ifadeleri içeren 46 maddeden oluşmaktadır. Cevaplama sistemi her ifade için "(5) Tamamen Uygun", "(4) Çoğunlukla Uygun", "(3) Kısmen Uygun", "(2) Biraz Uygun" ve "(1) Hiç Uygun Değil" olarak beşli Likert ölçeği seklindedir. Her bir maddenin puanları "5 ile I" arasında değişmektedir. Ölçek maddelerinin 26'si olumlu 20'si olumsuz ifade seklindedir. Olumsuz ifadeleri $\mathrm{n}$ puanlaması tersine çevrilerek yapılmaktadır. Ölçeğin Cronbach alfa güvenirlik katsayısı .93; test-tekrar test güvenirlik katsayısı .86 olarak saptanmıştır (Tuzgöl Dost, 2005).

İçsel Dini Motivasyon Ölçeği; tek boyutlu olup ölçeği oluşturan maddeler yarıya bölme tekniği ile analiz edildiğinde, iki yarım ölçek arasındaki korelasyon katsayısı .76 olarak hesaplanmıştır. İçsel tutarlılık ölçütü olan Cronbach's alpha katsayısının .84 olduğu tespit edilmiştir (Karaca, 2001).

\section{Bulgular:}

Çalışmamıza 147 erkek, 147 kadın olmak üzere 294 birey katılmıştır. İlahiyat fakültesinden 129, Fen Edebiyat fakültesinden 94 ve mühendislik fakültesinden 71 öğrenci çalışmaya katılmıştır.

Tablo 1: Manevi Zekâ, İç Yönelimli Dindarlık, Affetme Esnekliği ve Öznel İyi Oluş Ortalamalarını Gösterir.

\begin{tabular}{|l|c|c|c|c|c|}
\hline & N & Min. & Max. & $\bar{X}$ & Std. Dev. \\
\hline Manevi Zekâ & 293 & 93,00 & 212,00 & $\mathbf{1 4 8 , 4 6}$ & 19,16 \\
\hline Affetme Esnekliği & 294 & 33,00 & 69,00 & $\mathbf{5 2 , 1 5}$ & 5,33 \\
\hline İç Yönelimli Dindarlık & 294 & 12,00 & 40,00 & $\mathbf{2 4 , 8 0}$ & 3,70 \\
\hline Öznel İyi Oluş & 294 & 114,00 & 372,00 & $\mathbf{1 5 1 , 3 6}$ & 19,08 \\
\hline
\end{tabular}

Türkiye İlahiyat Araştırmaları Dergisi Turkey Journal of Theological Studies [Tiad: 2602-3067]
Cilt / Vol : 1, Say1/Issue: 1 , 2017 
Manevi Zekanın İç Yönelimli Dindarlık, Affetme Esnekliği ve Öznel İyi Oluşla İlişkisi/ Relation of Spiritual Intelligence to Intrinsic Religiosity, Forgiveness Flexibility and Subjective Well-Being

Tablo 1'e göre gurubun manevi zekâ ortalaması $\bar{X}=148,46$, affetme esnekliği ortalaması $\bar{X}=52,15$, iç yönelimli dindarlık ortalaması $\bar{X}=24,80$, öznel iyi oluş ortalaması ise $\bar{X}=151$, 36 olarak hesaplanmıştır.

Tablo 2: Manevi Zekâ, İç Yönelimli Dindarlık, Affetme Esnekliği ve Öznel İyi Oluş Arasındaki İlişkiyi Gösterir.

\begin{tabular}{|c|c|c|c|c|c|}
\hline Correlations & & 1 & 2 & 3 & 4 \\
\hline \multirow{3}{*}{$\begin{array}{c}1 \\
\text { Manevi Zekâ }\end{array}$} & $\mathrm{r}$ & 1 &, $188^{* *}$ &, $305^{* *}$ &, $151^{* *}$ \\
\hline & $\mathrm{p}$ & & 001 & ,000 & 010 \\
\hline & $\mathrm{n}$ & 293 & 293 & 293 & 293 \\
\hline \multirow{2}{*}{$\begin{array}{c}2 \\
\text { Affetme Esnekliği }\end{array}$} & $\mathrm{r}$ &, $188^{* *}$ & 1 &, $185^{* *}$ & ,077 \\
\hline & $\mathrm{p}$ & 001 & & ,001 & 190 \\
\hline \multirow{2}{*}{$\begin{array}{c}3 \\
\text { İç Yönelimli } \\
\text { Dindarlık }\end{array}$} & $\mathrm{r}$ &, $305^{* *}$ &, $185^{* *}$ & 1 & ,018 \\
\hline & $\mathrm{p}$ & ,000 & ,001 & & 758 \\
\hline \multirow{2}{*}{$\begin{array}{c}4 \\
\text { Öznel İyi Oluş }\end{array}$} & $\mathrm{r}$ &, $151^{* *}$ & ,077 & 018 & 1 \\
\hline & $p$ & 010 & ,190 & ,758 & \\
\hline
\end{tabular}

Tablo 2 incelendiğinde, manevi zekâ ile affetme esnekliği, iç yönelimli dindarlık arasında anlamlı bir ilişki gözlenmiştir. MZ/AE için $r=188, p=, 001, p<, 01$. MZ/IYD, r= 305, p=,000, p<,01. MZ/ÖİO, r= 151, p=,010, p<,05. Affetme esnekliği ile iç yönelimli dindarlık ortalamaları arasında anlamlı bir ilişki gözlenmiştir. $r=185, p=, 001, p<, 01$.

Tablo 3: Manevi Zekâ, İç Yönelimli Dindarlık, Affetme Esnekliği ve Öznel İyi Oluş Ortalamalarının Fakültelere Göre Dağılımını Gösterir.

\begin{tabular}{|c|c|c|c|}
\hline & Fakülte & $\mathrm{N}$ & $\overline{\mathrm{X}}$ \\
\hline \multirow{3}{*}{ Manevi Zekâ } & İlahiyat & 129 & $\mathbf{1 4 7 , 9 6}$ \\
\cline { 2 - 4 } & Fen Edebiyat & 94 & $\mathbf{1 4 9 , 1 0}$ \\
\cline { 2 - 4 } & Mühendislik & 71 & $\mathbf{1 4 8 , 5 4}$ \\
\hline \multirow{3}{*}{ Affetme Esnekliği } & İlahiyat & 129 & 52,07 \\
\cline { 2 - 4 } & Fen Edebiyat & 94 & $\mathbf{5 2 , 3 7}$ \\
\cline { 2 - 4 } & Mühendislik & 71 & 52,00 \\
\hline & İlahiyat & 129 & $\mathbf{2 4 , 8 5}$ \\
\hline
\end{tabular}


Ahmet Canan KARAKAŞ

\begin{tabular}{|c|c|c|c|}
\hline \multirow{2}{*}{$\begin{array}{c}\text { İç Yönelimli } \\
\text { Dindarlık }\end{array}$} & Fen Edebiyat & 94 & $\mathbf{2 4 , 6 0}$ \\
\cline { 2 - 4 } & Mühendislik & 71 & $\mathbf{2 4 , 9 6}$ \\
\hline \multirow{3}{*}{ Öznel İyi Oluş } & İlahiyat & 129 & $\mathbf{1 5 1 , 5 7}$ \\
\cline { 2 - 4 } & Fen Edebiyat & 94 & 149,26 \\
\cline { 2 - 4 } & Mühendislik & 71 & $\mathbf{1 5 3 , 7 7}$ \\
\hline
\end{tabular}

Tablo 3 incelendiğinde fakülte türlerine göre manevi zekâ en yüksek ortalamanın Fen Edebiyat Fakültesi öğrencilerine ait olduğu gözlenmiştir. $\bar{X}=149,10$. En düşük ortalama ise $\bar{X}=147,96$ ile ilahiyat Fakültesi öğrencilerine ait olduğu görülmüştür. Affetme esnekliği en yüksek ortalamaya $\bar{X}=52,37$ ile Fen Edebiyat fakültesi öğrencilerinin sahip olduğu görülmüştür. İç Yönelimli Dindarlık ortalamasının $\bar{X}=24,96$ ile mühendislik fakültesi öğrencilerine ait olduğu gözlenmiştir. Öznel iyi oluş en yüksek ortalamasının ise $\bar{X}=153,77$ ile mühendislik fakültesine ait olduğu görülmüştür.

Tablo 4: Manevi Zekâ, İç Yönelimli Dindarlık, Affetme Esnekliği ve Öznel İyi Oluş Ortalamalarının Cinsiyete Göre Dağılımını Gösterir.

\begin{tabular}{|c|c|c|c|c|}
\hline \multicolumn{2}{|c|}{ Cinsiyet } & N & $\bar{X}$ & Std. Dev. \\
\hline \multirow{2}{*}{ Manevi Zekâ } & Kadın & 147 & $\mathbf{1 4 9 , 6 5}$ & 19,54 \\
\cline { 2 - 5 } & Erkek & 147 & 147,27 & 18,76 \\
\hline \multirow{2}{*}{ Affetme Esnekliği } & Kadın & 147 & $\mathbf{5 2 , 3 3}$ & 5,41 \\
\cline { 2 - 5 } & Erkek & 147 & 51,97 & 5,26 \\
\hline \multirow{2}{*}{ İç Yönelimli Dindarlık } & Kadın & 147 & $\mathbf{2 5 , 0 0}$ & 3,47 \\
\cline { 2 - 5 } & Erkek & 147 & 24,59 & 3,92 \\
\hline \multirow{2}{*}{ Öznel İyi Oluş } & Kadın & 147 & 149,26 & 13,49 \\
\cline { 2 - 5 } & Erkek & 147 & $\mathbf{1 5 3 , 4 7}$ & 23,22 \\
\hline
\end{tabular}

Tablo 4 incelendiğinde değişkenlerin cinsiyete göre dağılımları görülmektedir. Manevi zekâ ortalamasında kadınların daha yüksek olduğu gözlenmiştir. $\bar{X}=149,65$. Affetme esnekliği ortalamasında kadınların $\bar{X}=52,33$ ile daha yüksek olduğu gözlenmiştir. İç yönelimli dindarlık ortalamasında yine kadınların $\bar{X}=25$ ile erkeklerden daha fazla olduğu gözlenmiştir. Öznel iyi oluş ortalamasında ise erkeklerin $\bar{X}=153,47$ ile kadınlardan daha fazla olduğu gözlenmiştir. Bu durumda erkeklerin kendilerini kadınlara göre daha iyi hissettiği söylenebilir.

Tablo 5: Manevi Zekânın Diğer Değişkenlere Etkisini Gösteren Regresyon Modeli.

\begin{tabular}{|c|c|c|}
\hline \multicolumn{3}{|c|}{ Model Summaryd } \\
\hline Model & R Square & \\
\hline$\frac{1 \lambda}{\underbrace{2017}}$ & $\begin{array}{c}\text { Türkiye İlahiyat Araştırmaları Dergisi } \\
\text { Turkey Journal of Theological Studies } \\
\text { [Tiad: 2602-3067] }\end{array}$ & $\begin{array}{l}\text { Cilt / Vol : 1, } \\
\text { Sayı/Issue: } 1, \\
\quad 2017\end{array}$ \\
\hline
\end{tabular}


Manevi Zekanın İç Yönelimli Dindarlık, Affetme Esnekliği ve Öznel İyi Oluşla İlişkisi/ Relation of Spiritual Intelligence to Intrinsic Religiosity, Forgiveness Flexibility and Subjective Well-Being

\begin{tabular}{cccccc}
\hline & & $\begin{array}{c}\text { Std. Error of } \\
\text { the } \\
\text { Estimate }\end{array}$ & df1 & df2 & Sig. F Change \\
\hline $\mathbf{1}$ & 0,035 & 18,82 & 1 & 292 & 0,001 \\
\hline $\mathbf{2}$ & 0,111 & 18,10 & 1 & 291 & 0,000 \\
\hline $\mathbf{3}$ & 0,129 & 17,94 & 1 & 290 & 0,014 \\
\hline
\end{tabular}

a. Affetme Esnekliği

b. Affetme Esnekliği, İç Yönelimli Dindarlık

c. Affetme Esnekliği, İç Yönelimli Dindarlık, ÖİO

\section{d. Dependent Variable: MZ}

Tablo 5 incelendiğinde, affetme esnekliği manevi zekanın \%3,5 ni anlamlı düzeyde açıklamaktadır. Affetme esnekliği ile iç yönelimli dindarlık manevi zekanın \%11 ni, affetme esnekliği, iç yönelimli dindarlık ve öznel iyi oluş manevi zekanın \%12,9 nu anlamlı düzeyde açıklamaktadır. Bu durumda manevi zekâ iç yönelimli dindarlıkla affetme esnekliğini daha fazla etkilediği bir başka deyişle; manevi zekâ geliştikçe bireylerde iç yönelimli dindarlık ve affetme esnekliği gelişebileceği söylenebilir.

\section{Tartışma ve Sonuç:}

Manevi zekâ yerli literatüre henüz yeni girmeye başlamış bir kavramdır. Bu anlamda sınırlı çalışmalara rastlanmıştır.

Bu çalışmanın sonunda manevi zekanın affetme esnekliği ile MZ/AE için $r=188, p=, 001$, $\mathrm{p}<, 01$, iç yönelimli dindarlık ile MZ/IYD, $r=305, \mathrm{p}=, 000, \mathrm{p}<, 01$ ve öznel iyi oluş ile MZ/ÖİO, $\mathrm{r}=151, \mathrm{p}=, 010, \mathrm{p}<, 05$ arasında anlamlı düzeyde pozitif ilişki olduğu gözlenmiştir. Bu sonuçlara göre bireyin manevi zekâsı arttıkça affetme esnekliği becerisi, iç yönelimli dindarlığı ve öznel iyi oluşu (iç huzur) artabilir. Burada en yüksek pozitif ilişki manevi zekâ ile iç yönelimli dindarlık arasında gözlenmiştir. Manevi zekanın ruhsallıkla ilintili olduğu hatırlanırsa, bireylerin katılacağı/icra edeceği manevi alıştırmalar kişinin bu zekasının gelişmesine katkıda bulunabilir. Böylelikle rabbiyle olan muamelatında daha samimi içten bir ilişki kuracaktır. İlişkinin pozitif yapılandırılması diğer insani ilişkilerine de yansıyabilir böylelikle kusurları affetme becerisi geliştirebilir. Tüm bunların sonunda iç huzura ulaşabilir. Yapılan bir çalışmada manevi zekanın yaşamın anlamı ve yaşam doyumu ile arasında anlamlı düzeyde pozitif ilişkiler bulgulanmıştır (Söylemez, 2016). Manevi zekâ müdahaleli bir çalışmada manevi zekanın ruh sağlığını iyileştirici etkisi görülmüştür. Manevi zekanın müdahalesinin, deney grubundaki kişilerarası duyarlılık, somatizasyon, obsesif kompulsiflik, depresyon, anksiyete, saldırganlık, fobik, paranoid düşünce ve psikoz miktarında kontrol grubuna kıyasla önemli bir azalmaya yol açtığını açık bir şekilde ortaya koymuştur (Charkhabi, Mortazavi, Alimohammadi, \& Hayati, 2014).

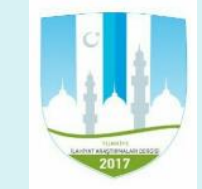

Türkiye İlahiyat Araştırmaları Dergisi

[Tiad] 
Değişkenlerin fakülteler arası ortalamaları incelendiğinde fakülteler arasında anlamlı bir farklılık gözlenmemiştir.

Manevi zekâ ortalaması en yüksek fakültenin Fen Edebiyat fakültesi olduğu $\bar{X}=149,10$, en düşük ortalamanın ise ilahiyat fakültesi olduğu $\bar{X}=147,96$ görülmüştür. Bu sonuç manevi zekanın tanımları hatırlandığında manevi zekanın sadece din ve dindarlıkla ilişkili olmadığını tekrarlamaktadır. Affetme esnekliği ortalamasında en yüksek ortalamaya sahip Fen Edebiyat fakültesi öğrencileri olduğu gözlenmiştir, $\bar{X}=52,37$. İç yönelimli dindarlık ortalaması en yüksek fakülte ise mühendislik fakültesi öğrencileri olduğu gözlenmiştir, $\bar{X}=24,96$. Mühendislik fakültesi öğrencilerinin dindarlığ 1 daha çok içselleştirdikleri söylenebilir. Öznel iyi oluş ortalamalarında en yüksek puan yine mühendislik fakültesine ait olduğu gözlenmiştir, $\bar{X}=153,77$. Bu sonuçlara göre içsel dindarlıkları yüksek olan mühendislik fakültesi öğrencilerinin daha huzurlu olabileceği söylenebilir. Yapılan bir çalışmada lise öğrencilerinde dindarlık ile öznel iyi oluş arasında pozitif yönlü ve anlamlı ilişkiler olduğu ve dindarlığın öznel iyi oluşu tüm alt boyutları ile pozitif yönlü ve anlamlı düzeyde yordadığı gözlenmiştir (Öztürk, 2017). Manevi iyi oluş ile dindarlık arasındaki ilişkiyi inceleyen bir araştırmada din ve dindarlığın manevi iyi oluş üzerinde pozitif etkisi gözlenmiştir (Acar, 2014). Dini inançların birey hayatındaki etkisinin derinliğini ölçmek için kullanılan içsel dini motivasyon oranları ile de öznel iyi olma halinin pozitif ilişki içerisinde olduğu görülmüştür (Balc1 , 2011). Bu sonuç ile araştımamızda ulaşılan sonuca göre iç yönelimli motivasyonel dindarlık arttıkça bireyin ruh halinde de istendik değişim ve gelişim olabilir.

Değişkenlerin cinsiyete göre aralarında anlamlı bir fark olmadığ 1 gözlenmiştir. Kadınların manevi zekâ, affetme esnekliği ve iç yönelimli dindarlık ortalamaları erkeklere göre daha yüksek olduğu gözlenmiştir. Erkeklerin ise öznel iyi oluş ortalamaları kadınlarınkinden daha yüksek olduğu görülmüştür, $\bar{X}=153,47$. Bu sonuç erkeklerin hayata daha pozitif baktıkları ve kadınlardan daha huzurlu oldukları şeklinde yorumlanabilir.

Yapılan regresyon analiz sonuçlarına göre affetme esnekliği, iç yönelimli dindarlık ve öznel iyi oluşun manevi zekanın \%13'nü açıkladığı gözlenmiştir, $\mathrm{R}^{2}=, 136$. Bu sonuca göre öznel iyi oluşun manevi zekanın bir boyutu değil bir sonucu olabileceği söylenebilir.

Manevi zekâ ruhun zekâsı olduğuna göre, ruhu nefsin zulmetinden kurtarmaya, onun benliğimizi sarmasına yönelik, ikincil niyetler taşımadan safiyane gayretlerle geliştirerek manevi zekamızı geliştirebiliriz.

Bu meyanda öncelikli olarak din eğitimi veren orta ve yüksek okullarda kuru bilgi ve dindarlıktan ziyade irfan ve ona dayalı samimi dindarlık sunacak enstrümantaller geliştirilebilir.

Bireylere ibadetler anlatılırken, ilmihal bilgileri yanında onların psiko-sosyal kazanımları paylaşılarak bireyler ibadete teşvik edilebilir.

\section{Kaynakça}

Acar, H. (2014). Manevi İyi Oluş İle Dindarlık Arasındaki İlişki Üzerine Bir Değerlendirme. C.Ü. İlahiyat Fakültesi Dergisi, 391-412.

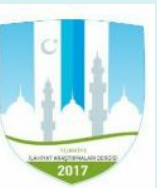


Manevi Zekanın İç Yönelimli Dindarlık, Affetme Esnekliği ve Öznel İyi Oluşla İlişkisi/ Relation of Spiritual Intelligence to Intrinsic Religiosity, Forgiveness Flexibility and Subjective Well-Being

Ayten, A. (2009b). Affedicilik ve Din: Affetme Eğilimi ve Dindarlıkla İlişkisi Üzerine Ampirik Bir Araştırma. M.Ü. İlahiyat Fakültesi Dergisi, 37 (2), 111-128.

Balc1 , F. (2011). Psikolojik ve Öznel İyi Olma Hali İle Dini İnançlar Arasındaki İlişki Üzerine Bir Inceleme (Yayınlanmamış Y.L. Tezi). Bursa: Uludağ Üniversitesi Sosyal Bilimler Üniversitesi.

Ben-Zur, H. (2003). Happy Adolescents: The Link Between Subjective Well-Being, Internal Resources, and Parental Factors. Journal of Youth and Adolescence, 32(2), 67-79.

Charkhabi, M., Mortazavi, A., Alimohammadi, S. \& Hayati, D. (2014). The Effect of Spiritual Intelligence Training on the Indicators of Mental Health in Iranian Students: An Experimental Study. Procedia - Social and Behavioral Sciences, 355-358.

Çolak, T. (2013). Affetme Esnekliği Kazandırmada Logoterapi Yönelimli Gurupla Psikolojik Danışmanın Etkililiği. SAÜ Ĕ̆itim Bilimleri Enstitüsü.

Çolak, T., \& Koç, M. (2016). Forgiveness Flexibility. International Journal of Psychology and Educational Studies, 3(1), 14-30.

Diener, E., \& Diener, C. (1996). Most People are Happy. Psychological Science, 181-185.

Diener, E., Suh, E., \& Oishi, S. (1997). Recent Finding on Subjective Well Being. Journal of Clinical Psychology, 1-24.

Emmons, R. (2008). Maneviyat Bir Zekâ mıdır? Güdülenme, Biliş ve Nihaî İlgi Psikolojisi. (A. Mehmedoğlu, \& F. Şengül, Dü) M.Ü. İlâhiyat Fakültesi Dergisi, 133-158.

Enright, R., Gassin, E., \& Wu, C. (1992). Forgiveness: A Developmental View. Journal of Moral Education, 21(2), 99-114.

Howard, B., Guramatunhu-Mudiwa, P., \& White, S. (2009). Spiritual Intelligence and Transformational Leadership: A New Theoritical Framework. Journal of Curriculum and Instruction, 3(2), 54-67.

Karaca, F. (2001). Din Psikolojisinde Metot Sorunu Ve Bir Dindarlık Ölçeğinin Türk Toplumuna Standardizasyonu. EKEV, 187-201.

Karaca, F. (2011). Din Psikolojisi. Trabzon: Eser Ofset.

Koç, M., İskender, M., Çolak, T., \& Düşünceli, B. (2016). Investigation of the Effect of Intolerance of Uncertainty and the effect of Anger Control on the Relationship between Forgiveness and Psychological Well-Being through Structural Equation Modelling. Sakarya University Journal of Education, 6(3), 201-209.

Kuyumcu, B. (2011). Üniversite Öğrencilerinin Duygusal Farkındalık Duyguları İfade Etme Benlik Kurgusu ve Öznel İyi Oluş Durumları Arasındaki İlişkinin İncelenmesi. Uluslar arası Sosyal Bilimler Eğitimi Dergisi, 104-113.

Lin W, E. R. (2004). Effect of Forgiveness Therapy on Anger, Mood and Vulnerability to Substance Use Among İnpatient Substance-Dependent Clients. Journal of Consulting and Clinical Psychology., 72, 1114-1121. 
McCullough, M., \& Witvliet, C. (2002). The Psychology of Forgiveness. C. Snyder, \& S. Lopez içinde, Handbook of Positive Psychology (s. 449). Oxford University Press.

Öztürk, Y. (2017). Ergenlerde Dindarlık ile Öznel İyi Oluş Arasındaki İlişkinin İncelenmesi (Çarşamba Örneği). Çorum: Hitit Üniversitesi Sosyal Bilimler Enstitüsü.

Söylemez, A. (2016). Manevi Zekanın Yaşamın Anlamı ve Yaşam Doyumunun Yordayıcısı Olarak İncelenmesi (Yayınlanmamış Y.L Tezi). Sakarya: SAÜ Eğitim Bilimleri Ensttüsü.

Söylemez, A., Koç, M., \& Söylemez , B. (2016). The Adaptation of Integrated Spiritual Intelligence Scale into Turkish. Journal of Family, Counseling, and Education, 18-24.

Türkdoğan, T., \& Duru, E. (2012). Üniversite Öğrencilerinde Öznel İyi Oluşun Yordanmasında Temel İhtiyaçların Karşılanmasının Rolü. Kuram ve Uygulamada Ĕ̆itim Bilimleri, 12(4), 2429-2446.

Zohar, D., \& Marshall, I. (2014). SQ: Ruhsal Zekâmızla Bağlantı Kurmak. İstanbul: Meta Yayınları. 